\title{
RELAKSASI KESADARAN INDERA UNTUK MENURUNKAN TINGKAT KECEMASAN PENDERITA DIABETES MELLITUS
}

\section{SENSORY RELAXATION AWARENESS TO LOWER ANXIETY AMONG DIABETES MELLITUSS PATIENT}

\author{
Baiq Ratna Ayunsari, \\ Siti Suminarti Fasikhah \\ Diah Karmiyati \\ Fakultas Psikologi Universitas Muhammadiyah Malang \\ E-mail: ayunsari@yahoo.com / fasikhahss@yahoo.com
}

\begin{abstract}
This study was aimed to reveal the influence of sensory awareness relaxation to reduce the anxiety felt by patients with diabetes mellitus. This study was a single case study. The design in this study using $A B A$ design. Subjects in this study amounted to two men who are diagnosed with diabetes mellitus and anxiety. Selection of subjects with anxiety viewed using Subjective Units of Discomfort Scale (Suds) and the Beck Anxiety Inventory (BAI). The study was conducted starting from the pre-therapy, therapy, after therapy, and follow-up for seven sessions and one week to monitor the condition of the subject after therapy is stopped. In this study using two male subjects. These results indicate that sensory awareness relaxation can reduce the anxiety felt by patients with diabetes mellitus.
\end{abstract}

Key Words: Sensory Awareness Relaxation, Anxiety, Diabetes Mellitus

\begin{abstract}
ABSTRAK
Penelitian ini bermaksud mengetahui efektivitas terapi relaksasi kesadaran indera dalam menurunkan tingkat kecemasan terhadap penyakit kronis yang dialami oleh klien. Penelitian ini merupakan penelitian kasus tunggal. Desain dalam penelitian ini menggunakan desain ABA. Subjek dalam penelitian ini berjumlah dua orang yang didiagnosis menderita penyakit diabetes mellitus dan mengalami kecemasan. Pemilihan subjek yang mengalami kecemasan dilihat dengan menggunakan Subjective Units of Discomfort Scale (SUDs) dan Beck Anxiety Inventory (BAI). Penelitian dilakukan mulai dari pra terapi, terapi, pasca terapi, dan follow-up selama tujuh sesi dan satu minggu untuk memantau kondisi subjek setelah terapi dihentikan. Hasil penelitian ini menunjukkan bahwa relaksasi kesadaran indera mampu menurunkan kecemasan yang dirasakan oleh pasien penderita penyakit diabetes mellitus.
\end{abstract}

Kata Kunci: Relaksasi Kesadaran Indera, Kecemasan, Diabetes Mellitus 
Diabetes mellitus (DM) adalah suatu penyakit di mana kadar glukosa (gula sederhana) di dalam darah tinggi karena tubuh tidak dapat melepaskan atau menggunakan insulin secara adekuat. Menurut American Diabetes Association, DM adalah penyakit metabolis dengan karakteristik hiperglikemia (peningkatan glucose pada darah) yang terjadi karena kelainan sekresi insulin, kerja insulin, atau keduanya. Saat produksi insulin sel betta terganggu kemampuan tubuh melakukan metabolisme glukosa menurun dan kadar gula darah meningkat tajam (Kartika \& Hasanat, 2008).

Penderita penyakit DM ini secara signifikan terus bertambah dari tahun ke tahun. Laporan data epidemiologi McCarty dan Zimmet (Kartika \& Hasanat, 2008) menunjukkan bahwa jumlah penderita DM di dunia dari 110,4 juta pada tahun 1994 melonjak dua kali lipat (239,3 juta orang) pada tahun 2010. Di Indonesia sendiri pada tahun 1994 jumlah penderita DM sekitar 2,5 juta orang, kemudiaan pada tahun 2000 menjadi empat juta orang dan diperkirakan pada tahun 2010 jumlah penderita DM minimal lima juta orang. Sedangkan data dari WHO menunjukkan pada tahun 1995 Indonesia berada pada urutan ke tujuh dan pada tahun 2025 jumlah penderita DM diperkirakan meningkat ke posisi kelima terbesar di dunia.

Menurut David (Ambarwati, 2008), penyakit diabetes adalah penyakit yang kronik dan tidak bisa sembuh sempurna, perlu perawatan seumur hidup, dan dapat menimbulkan perubahan psikologis yang mendalam pada penderita, keluarga dan kelompok sosialnya. Individu yang terkena label DM harus memakai label tersebut seumur hidupnya. Penderita DM harus selalu menjaga pola makan, olah raga rutin, melakukan check-up, bahkan dapat dikatakan harus mengubah seluruh pola hidupnya.

Individu yang belum dapat menerima kenyataan bahwa dirinya menderita DM seringkali menunjukkan berbagai perubahan perilaku dan perasaan, seperti perasaan menjadi tidak adekuat lagi, timbul ketakutan, kecemasan, menuntut dirawat orang lain dengan berlebihan dan mereka mengembangkan sikap permusuhan. Oleh karena itu, penderita diabetes seringkali diasosiasikan dengan gangguan psikososial, yaitu depresi, kecemasan, ketegangan dan stres yang menekan (Ambarwati, 2008). Hal ini juga dirasakan oleh kedua klien dalam penelitian ini yang didiagnosis mengidap penyakit diabetes mellitus disertai hipertensi dan gastritis akut oleh dokter.

Menurut Hudak dan Galo (1995), perasaan-perasaan takut dan cemas yang dirasakan pasien dikarenakan oleh rasa ketidakberdayaan, ketakutan akan ditinggalkan oleh keluarga dan temanteman, rasa tidak aman serta yang paling menimbulkan kecemasan adalah bahwa dirinya sewaktu-waktu dapat meninggal. Perasaan-perasaan takut yang dialami 
oleh pasien tersebut akan menimbulkan kecemasan, dan perasaan cemas yang terus menerus akan memberikan pengaruh yang semakin memperburuk kesehatan pasien itu sendiri. Hal ini dikarenakan adanya hubungan antara emosi dengan kesehatan fisik. Menurut Felten (Goleman, 1996), emosi berpengaruh secara dahsyat terhadap sistem syaraf autonom yang mengatur segala macam, mulai dari jumlah insulin yang dikeluarkan tubuh sampai tingginya tingkat tekanan darah.

Pendapat ini diperkuat oleh pendapat Nezhat (Goleman, 1996), seorang ahli bedah, yang mengatakan bahwa jika seorang yang telah dijadwalkan untuk melakukan sebuah operasi merasa panik dan cemas maka dia akan membatalkan operasinya. Alasannya karena rasa panik dan cemas dapat meningkatkan tekanan darah dan pembuluh darah yang melebar akibat meningkatnya tekanan darah. Hal ini selanjutnya akan banyak mengeluarkan darah apabila dipotong. Pendarahan yang hebat merupakan salah satu komplikasi operasi yang dapat menyebabkan kematian.

Penelitian lain yang dilakukan oleh Afiah (2010) pada penderita penyakit diabetes yang juga merupakan salah satu penyakit kronis memberikan hasil bahwa pasien yang didiagnosis menderita penyakit DM dan mengalami kecemasan akan mengakibatkan meningkatnya kadar gula dalam darahnya, sehingga menyebabkan tidak pernah stabilnya kadar gula dalam darah yang bisa berakibat fatal bagi organ tubuh lainnya. Hal ini disebabkan adrenalin yang ditimbulkan ketika pasien mengalami kecemasan akan memengaruhi kerja insulin yang berfungsi untuk mengeluarkan glukosa dalam darah. Melihat hasil penelitian di atas, maka tampak bahwa kecemasan yang dirasakan oleh penderita DM dapat berpengaruh pada penyakitnya dan bisa berakibat fatal bagi hidup penderita diabetes. Melihat prevalensi penderita yang semakin meningkat dan bahaya dari dampak kecemasan terhadap perkembangan penyakit ini, dirasa perlu untuk melakukan sebuah cara untuk mengurangi kecemasan tersebut. Oleh karenanya, dalam penelitian ini diajukan sebuah metode relaksasi untuk menurunkan tingkat kecemasan penderita penyakit kronis agar semua resiko yang diakibatkan oleh kecemasan terhadap penyakit diabetes dapat dicegah.

Selamasistem-sistemberfungsinormal dalam keseimbangan, bertambahnya aktivitas sistem yang satu akan menghambat atau menekan efek sistem yang lain. Pada waktu orang mengalami ketegangan dan kecemasan yang bekerja adalah sistem saraf simpatetis, sedangkan pada waktu rileks yang bekerja adalah sistem saraf parasimpatetis. Dengan demikian relaksasi dapat menekan rasa tegang dan rasa cemas dengan resiprok, sehingga timbul counter conditioning dan penghilangan (Subandi, 2002) 
Dasar pikiran relaksasi adalah sebagai berikut. Relaksasi merupakan pengaktifan dari saraf parasimpatetis yang menstimulasi turunnya semua fungsi yang dinaikkan oleh sistem saraf simpatetis, dan menstimulasi naiknya semua fungsi yang diturunkan oleh saraf simpatetis. Masing-masing saraf parasimpatetis dan simpatetis saling berpengaruh. Karenanya, bertambahnya salah satu aktivitas sistem yang satu akan menghambat atau menekan fungsi yang lain (Subandi, 2002). Relaksasi dapat digunakan sebagai active coping skill jika digunakan untuk mengajar individu kapan dan bagaimana menerapkan relaksasi di bawah kondisi yang diinginkan, misalnya digunakan untuk mengurangi gangguan insomnia, mengurangi kecemasan atau untuk membuat tubuh istirahat sejenak. Apabila individu melakukan relaksasi ketika mengalami ketegangan atau kecemasan, maka reaksi-reaksi fisiologis yang dirasakan individu akan berkurang, sehingga ia akan merasa rileks. Apabila kondisi fisiknya sudah rileks, maka kondisi psikisnya juga tenang (Purwanto, 2006).

Teknik relaksasi banyak digunakan untuk menangani penderita penyakit kronik termasuk penderita kanker, karena dapat menurunkan kecemasan dan mual akibat kemoterafi dan radioterafi serta menurunkan nyeri pada penderita kanker (Taylor, 1995). Di samping itu, Kaplan dkk (1997) mengatakan bahwa relaksasi dapat menghasilkan efek fisiologis yang berlawanan dengan kecemasan, seperti kecepatan denyut jantung yang lambat, peningkatan aliran darah perifer dan stabilitas neuromuskular.

Burn (Subandi, 2002) melaporkan beberapa keuntungan yang diperoleh dari latihan relaksasi. Salah satunya adalah untuk mengurangi tingkat kecemasan. Ada beberapa bukti bahwa individu dengan tingkat kecemasan yang tinggi dapat menunjukkan efek fisiologis positif melalui latihan relaksasi. Selain itu juga, relaksasi dapat mengurangi kemungkinan gangguan yang berhubungan dengan stres, dan mengontrol anticipatory anxiety sebelum situasi yang menimbulkan kecemasan, seperti pada pertemuan penting, wawancara dan sebagainya. Beberapa penelitian menunjukkan bahwa relaksasi dapat mengurangi kecemasan pada waktu wawancara bagi pasien psikiatri (Subandi, 2002).

Pelatihan relaksasi semakin sering dilakukan karena dari hasil penelitianpenelitian yang dilakukan Jacobson dan Wolpe terbukti bahwa relaksasi secara efektif dapat mengurangi ketegangan dan kecemasan (Ramdhani, tanpa tahun). Teknik relaksasi ada beberapa macam yaitu relaksasi otot, relaksasi kesadaran indera, relaksasi melalui hipnosa, yoga, dan meditasi. Namun melihat kondisi pasien yang mengidap penyakit kronis dan sebagian juga mengalami konflikasi dengan tekanan darah tinggi sehingga dilakukan relaksasi dengan menggunakan relaksasi kesadaran indera. Relaksasi 
kesadaran indera ini dikembangkan oleh Golfried yang dipelajarinya dari Weitzman (Subandi, 2002). Relaksasi kesadaran indera ini memfokuskan individu untuk bisa merasakan tubuhnya sendiri khususnya panca indera sehingga individu bisa merasakan ketenangan.

Pada teknik relaksasi kesadaran indera ini, klien diberi satu seri pertanyaan yang tidak untuk dijawab secara lisan namun untuk dirasakan sesuai dengan apa yang dapat dan tidak dapat dialami individu pada waktu instruksi diberikan, sehingga klien diharapkan untuk bisa mengalami kondisi rileks yang mendalam untuk membantu klien mengurangi rasa cemas yang sedang dihadapinya. Menurut Desminarti (2003) dalam penelitiannya tentang relaksasi kesadaran indera pada penderita kanker payudara bahwa pemberian relaksasi kesadaran indera pada penderita kanker payudara melalui kaset sama efektifnya jika dibandingkan dengan relaksasi kesadaran indera yang diberikan melalui liflet.

Sementara itu, kecemasan atau dalam Bahasa Inggrisnya "anxiety" berasal dari Bahasa Latin yaitu "angustus" yang berarti kaku, dan "ango, anci" yang berarti mencekik (Pratiwi, 2010). Menurut Freud (Semium, 2006) mengatakan bahwa kecemasan adalah fungsi ego untuk memperingatkan individu tentang kemungkinan datangnya suatu bahaya sehingga dapat disiapkan reaksi adaptif yang sesuai. Kecemasan berfungsi sebagai mekanisme yang melindungi ego karena kecemasan memberi sinyal kepada kita bahwa ada bahaya dan kalau tidak dilakukan tindakan yang tepat maka bahaya itu akan meningkat sampai ego dikalahkan. Keadaan yang tidak menyenangkan ini sering kabur dan sulit menunjuk pada hal yang tepat, tetapi kecemasan itu sendiri selalu dirasakan.

Reaksi cemas terhadap situasi yang menekan merupakan bagian dari pengalaman manusia sehari-hari. Kecemasan memiliki tingkatan tertentu yaitu kecemasan yang wajar atau tidak. Kecemasan yang wajar tidak akan mengganggu kehidupan manusia seharihari, dan akan mendorong individu untuk lebih berhati-hati dalam menghadapi situasi yang mengancam (Pratiwi, 2010). Kecemasan sebagai sesuatu emosi yang muncul dari pengalaman subjektif individu biasanya tidak dapat dikenali secara nyata. Kecemasan merupakan perasaan subjektif yang dialami oleh individu. Hal ini disebabkan oleh situasi-situasi yang mengancam sehingga menyebabkan ketidakberdayaan individu (Semium, 2006). Kecemasan pada tingkat tertentu dapat dianggap sebagai bagian dari respon normal untuk mengatasi masalah sehari-hari. Kecemasan merupakan suatu penyerta normal dari pertumbuhan, perubahan, pengalaman sesuatu yang baru dan belum dicoba serta penemuan identitas diri dan juga menemukan arti hidup (Kaplan, dkk, 1997). 
Pengertian kecemasan menurut teori behavioristik menganggap kecemasan sebagai suatu respon yang telah dibiasakan terhadap stimulus yang spesifik. Kecemasan merupakan bentuk yang terkondisikan dari reaksi rasa sakit. Kecemasan memilki fungsi paling bermanfaat untuk memotivasi individu menghindar atau melindungi diri dari stimulus yang dapat mengakibatkan rasa sakit (Monte \& Sollod, 2003).

Kenyon (1985) berpendapat gejala utama dari kecemasan adalah bahwa mulut kering, merasa mual atau benarbenar muntah, berdebar-debar, nadi berdenyut dengan cepat, perut kembung, gemetaran, berkeringat, sering ingin buang air dan mencret-mencret. Selain itu mungkin adanya perasaan melayanglayang, kaki gemetaran, cepat tersinggung, menggigit kuku, merokok, makan atau minum-minuman keras terlalu banyak merupakan gejala dari kecemasan.

$\begin{array}{ccc}\text { Relaksasi } & \text { adalah salah satu } \\ \text { teknik dalam } & \text { terapi perilaku yang } \\ \text { dikembangkan } & \text { oleh Jacobson dan }\end{array}$
Wolpe untuk mengurangi ketegangan dan kecemasan. Penggunaan relaksasi memiliki sejarah yang luas dalam bidang kedokteran, psikologi klinis, \& psikiatri (Goldfried \& Davison, 1976). Oleh orang awam istilah relaksasi sering digunakan untuk menjelaskan aktivitas yang menyenangkan. Rekreasi, olah raga, pijat, dan nonton bioskop yang dilakukan untuk mendapatkan suasana rileks merupakan contoh yang banyak dikaitkan dengan relaksasi. Oleh karena efek yang dihasilkan adalah perasaan senang, relaksasi mulai digunakan untuk mengurangi ketegangan, terutama ketegangan psikis yang berkaitan dengan permasalahan kehidupan.

Menurut Suryani (dalam Susanti, 2009) relaksasi adalah salah satu cara untuk mengistirahatkan fungsi fisik dan mental sehingga menjadi rileks. Selain itu juga merupakan upaya untuk melupakan kecemasan dan mengistirahatkan pikiran dengan cara menyalurkan kelebihan energi atau ketegangan psikis melalui sesuatu kegiatan yang menyenangkan. Burn (Subandi, 2002) melaporkan beberapa keuntungan yang diperoleh dari latihan relaksasi adalah:

1. Relaksasi akan membuat individu lebih mampu menghindari reaksi yang berlebihan karena adanya stres.

2. Masalah-masalah yang berhubungan dengan stres seperti hipertensi, sakit kepala, insomnia dapat dikurangi atau diobati dengan relaksasi. Beberapa penelitian juga menunjukkan bahwa relaksasi dapat menurunkan tekanan darah systolic dan diastolic pada penderita hipertensi, mengurangi insomnia, dan mampu mengobati sakit kepala (Walker dkk, Heffler, dalam Subandi, 2002)

3. Mengurangi tingkat kecemasan. Ada beberapa bukti bahwa individu dengan tingkat kecemasan yang tinggi dapat menunjukkan efek fisiologis positif melalu latihan relaksasi. 
4. Mengurangi kemungkinan yang berhubungan dengan stres, dan mengontrol anticipatory anxiety sebelum situasi yang menimbulkan kecemasan, seperti wawancara dan pertemuan penting.

5. Menurunkan tingkat ketegangan.

6. Kelelahan, aktivitas mental dan atau latihan fisik yang tertunda dapat di atasi lebih cepat dengan menggunakan keterampilan relaksasi.

7. Relaksasi merupakan bantuan untuk menyembuhkan penyakit tertentu dan operasi.

Menurut Utami (Subandi, 2002), ada berbagai macam teknik relaksasi sebagaimana telah dikemukakan di atas, salah satu diantaranya adalah relaksasi kesadaran indera.. Dalam penelitian ini yang digunakan adalah relaksasi kesadaran indera yang dikembangkan oleh Golfried yang dipelajari oleh Weitzman (Goldfried \& Davison, 1976). Teknik ini tidak membutuhkan latihan otot atau ketegangan otot, yang apabila salah melakukannya maka akan menyebabkan rasa nyeri dan cedera otot. Di samping itu relaksasi kesadaran indera mengandung pengkondisian kata-kata isyarat rileks atau tenang terhadap pengalaman relaksasi yang dalam, serta diberikan gambarangambaran yang memberi induksi relaksasi (Subandi, 2002).

Respon kesadaran indera diperoleh melalui daya imajinasi seseorang dalam membayangkan dan merasakan sensasi indera pendengaran, penglihatan, penciuman, perabaan dan percakapan. Dengan kata lain respon relaksasi diperoleh melalui kegiatan imajeri (membayangkan) yang dilakukan oleh seseorang terhadap suatu yang pernah ia terima melalui alat indranya.

Menurut Davis (1995), kegiatan membayangkan atau kesan batin yang diciptakan dengan sadar dapat melatih diri menjadi rileks dan mengabaikan stres. Davis juga mengatakan bahwa untuk mengatasi perasaan tidak bahagia dan tegang, seseorang dapat mengubah pusat fikiran ke arah positif melalui bayangan yang ia ciptakan (penyembuhan dengan imajinasi).

Berdasarkan kerangka pemikiran di atas, melalui penelitian ini diharapkan relaksasi kesadaran indera dapat dijadikan alternatif intervensi yang dapat digunakan untuk membantu menurunkan tingkat kecemasan pada penderita penyakit diabetes. Peneliti juga berharap bahwa penelitian ini dapat memberikan gambaran mengenai kondisi psikologis yang terkait dengan kecemasan pada penderita penyakit diabetes jika penelitian ini terbukti dapat menurunkan tingkat kecemasan pada penderita penyakit diabetes tersebut. Dengan demikian, hipotesis yang diajukan dalam penelitian ini adalah relaksasi kesadaran indera dapat digunakan untuk menurunkan kecemasan pasien penderita penyakit diabetes mellitus. 


\section{METODE PENELITIAN}

\section{Subjek Penelitian}

Subjek penelitian dalam penelitian ini adalah pasien yang datang berobat ke praktek dokter dan didiagnosis menderita penyakit diabetes serta mengalami kecemasan dengan penyakitnya tersebut. Jenis kelamin tidak dibatasi karena jenis kelamin tidak diteliti dalam peneltian ini. Subjek penelitian ini berjumlah dua orang yang terdiagnosis terkena diabetes. Adapun karakteristik subjek yang diambil dalam penelitian ini adalah:

1. Subjek penelitian berusia antara 30-55 tahun berjenis kelamin lakilaki maupun perempuan.

2. Subjek merupakan pasien yang didiagnosis menderita penyakit diabetes.

3. Subjek mengalami kecemasan terhadap penyakit yang sedang dideritanya dan diukur dengan alat ukur kecemasan BAI.

\section{Rancangan Penelitian}

Rancangan penelitian yang digunakan adalah rancangan penelitian dengan single case design ABA design. A dalam penelitian ini adalah fase baseline atau fase sebelum terapi, sedangkan B adalah fase terapi dan A yang kedua adalah fase tindak lanjut. Pada penelitian ini subjek diberikan pengukuran sebelum dan sesudah pemberian perlakuan pada subjek. Perbedaan kedua hasil pengukuran dianggap sebagai efek perlakuan (Latipun, 2002).

\section{Metode Pengumpulan Data}

Pengumpulan data menggunakan beberapa metode berikut:

1. Daftar riwayat hidup, yaitu metode yang berisi tentang data demografi mengenai identitas subjek, meliputi tempat tinggal, status perkawian, agama dan latar belakang keluarga, kesehatan, dan riwayat pendidikan. Metode ini diberikan kepada subjek pada saat asesmen awal.

2. Wawancara, yaitu pertemuan dua orang untuk bertukar informasi dan ide untuk bertukar informasi dan ide melalui tanya jawab, sehingga dapat dikonstruksikan makna dalam suatu topik tertentu. Ditambahkan juga bahwa dalam wawancara terdapat 3 teknik, yaitu wawancara terstruktur, semi terstruktur dan tidak terstruktur. Sedangkan dalam penelitian ini digunakan wawancara tidak terstruktur (Esterberg, dalam Sugiyono, 2010). Menurut Sugiyono (2010), wawancara tidak terstruktur adalah wawancara yang bebas dimana peneliti tidak menggunakan pedoman wawancara yang telah tersusun secara sistematis dan lengkap untuk pengumpulan datanya. Wawancara ini sering digunakan untuk mengawali penelitan dan mendapatkan data tentang klien secara lebih mendalam. Wawancara ini akan dilakukan dalam beberapa tahap yaitu : 

a. Praterapi
b. Selama proses terapi
c. Pascaterapi
d. Follow-up

3. Observasi, yaitu pengamatan langsung para pembuat keputusan berikut lingkungan fisiknya dan atau pengamatan langsung suatu kegiatan yang sedang berjalan. Observasi dilakukan selama proses terapi. Observasi dilakukan untuk mendapatkan data faktual selama sesi terapi, misalnya bagaimana tingkat keseriusan subjek dalam mengikuti setiap kegiatan, kemampuan mengungkapkan permasalahan mereka, serta bagaimana kemampuan subjek untuk melakukan latihan relaksasi sesuai dengan instruksi yang diberikan.

4. SUDs (Subjective Unit of Discomfort scale), yaitu penentuan range tingkat kecemasan berdasar pada apa yang dirasakan subjek.

5. Skala Kecemasan. Dalam penelitian ini pengumpulan data dilakukan dengan skala. Menurut Azwar (1999), istilah skala disamakan dengan istilah tes namun dalam pengembangan instrumen ukur, umumnya istilah tes digunakan untuk mengukur kemampuan kognitif sedangkan skala lebih banyak digunakan untuk mengukur aspek afektif. Skala kecemasan yang digunakan adalah skala BAI (Beck anxiety inventory) untuk mengungkap kecemasan yang menetap dalam diri individu. BAI ini dikembangkan oleh Aaron T. Beck dan teman-temannya dan merupakan skala psikologis yang terdiri dari 21 aitem dan berbentuk skala likert dengan range mulai dari 0-3 di mana angka ini mewakili frekuensi timbulnya simptom kecemasan yang dialami oleh klien untuk kepentingan klinis dan penelitian. Aitem-aitem yang terdapat pada $\mathrm{BAI}$ ini menggambarkan kondisi emosi, psikis dan kognitif yang merupakan simptom kecemasan dan bukan depresi. Skala kecemasan ini dijadikan sebagai acuan alat ukur tingkat kecemasan pada pasien penderita penyakit diabetes. Dalam penelitian ini skala kecemasan diberikan pada saat asesmen awal, fase akhir terapi (pasca terapi) dan ketika dilakukannya follow-up.

\section{Prosedur Intervensi}

Penelitian ini menggunakan prosedur sebagai berikut:

1. Penentuan subjek penelitian

Penentuan subjek penelitian berdasarkan kriteria kecemasan pasien yang didiagnosis menderita penyakit diabetes. Di sini ada keluhan gejalagejala fisiologi yang mengganggu begitu juga dengan psikologis. Dengan adanya kriteria tersebut, maka peneliti memutuskan meminta persetujuan subjek agar kasus yang dialami subjek dilakukan intervensi 
2. Identifikasi Kasus

Pada tahapan ini, peneliti menggali beberapa data tentang subjek. Peneliti juga mengklarifikasi permasalahan utama subjek, memz-bicarakan permasalahan yang dirasakan subjek secara lebih mendalam. Mengetahui kondisi subjek dengan mengetahui gejala kecemasan dan pemikiran negatif yang dirasakan subjek.

3. Melakukan kontrak penelitian

Mengingat pentingnya permasalahan yang dihadapi subjek, maka peneliti menawarkan agar subjek bersedia mengikuti proses intervensi serta menjadi subjek yang sangat mendukung dalam penelitian yang akan dilakukan. Peneliti menawarkan teknik terapi sebagai solusi atas permasalahan yang subjek alami. Menjelaskan prosedur dan jenis terapi yang akan diberikan kepada subjek, menjelaskan manfaat terapi, kemudian menetapkan target perubahan yang diharapkan. Tidak lupa peneliti memberi motivasi bahwa subjek bisa mengatasi kecemasan yang dialaminya.

4. Merancang pelaksanaan

Dalam hal ini terapi mengajak subjek untuk mempelajari prosedur yang dilakukan oleh subjek dan terapi sekaligus membuat kesepakatan mengenai perilaku apa saja yang akan di rubah, dan gejala apa saja dari kecemasan yang akan dirubah yang kemudian uraikan dalam self monitoring. Peneliti juga merancang teknik terapi yang digunakan untuk mengatasi kecemasan. Kemudian baru menyepakati jadwal pelaksanaan terapi dan tempatt dilaksanakannya terapi ini

5. Pelaksanaan terapi

Dalam penelitian ini intervensi yang digunakan adalah relaksasi kesadaran indera. Hal pertama kali yang dilakukan ada mengajarkan relaksasi kesadaran indera. Pada relaksasi ini subjek diminta untuk merasa lebih nyaman dan tenang dengan mendengarkan isntruksi dari terapis. Peneliti meminta subjek untuk menjawab pertanyaan yang diberikan. Menurut Subandi (2002), relaksasi kesadaran indera ini merupakan teknik relaksasi saat individu diberi satu seri pertanyaan yang tidak untuk dijawab secara lisan, tetapi untuk dirasakan sesuai dengan apa yang dapat atau tidak dapat dialami individu pada waktu instruksi diberikan.

6. Proses Penghentian Terapi

Terapi akan dihentikan ketika tujuan penelitian yang sudah disepakati dengann klien sudah tercapai yaitu: (1) Menurunnya tingkat kecemasan secara relatif cukup meyakinkan dari waktu ke waktu; (2) Tujuan atau terget terapi relatif sudah tercapai; (3) Subjek 
merasa sudah terbiasa menghadapi situasinya, cukup yakin pada dirinya sendiri untuk dapat menghadapi simtomnya sendiri tanpa bantuan dari peneliti lagi. Tahap ini dilakukan pada saat sesi terakhir.

7. Pemberian tugas rumah

Tugas rumah diberikan setelah subjek paham dan mengerti bagaimana melakukan relaksasi kesadaran indera. Subjek diminta untuk melakukan relaksasi sebanyak 1 kali dalam sehari dan disaat simtomsimtom kecemasan subjek muncul.

8. Follow-up

Tahap tindak lanjut ini akan dilakukan 2 minggu pasca dihentikannyaterapi. Halini bertujuan untuk mengetahui perubahan subjek setelah terapi ini dihentikan selama 2 minggu. Metode yang dilakukan dalam tahap ini adalah wawancara, dan membandingkan hasil BAI dan self report sebelum, selama dan setelah terapi.

Dalam penelitian ini, intervensi yang diberikan kepada subjek dimaksudkan untuk mengurangi kecemasan subjek dengan menggunakan relaksasi kesadaran indera. Dalam teknik kesadaran indera subjek akan diajak untuk lebih merasakan ketenangan dengan merasakan atau membayangkan dengan menggunkan indera. Adapun proses relaksasi kesadaran indera ini adalah sebagai berikut:
1. Dalam teknik ini individu diberikan satu seri pertanyaan yang tidak untuk dijawab secara lisan, tetapi untuk dirasakan sesuai dengan apa yang dapat atau tidak dapat dialami individu pada waktu instruksi diberikan.

2. Setiap pertanyaan yang diberikan masing-masing dapat dijawab dengan 'ya' atau 'tidak', tetapi tidak perlu menjawab dengan suara yang keras atau jawaban untuk diri sendiri, karena jawaban dari masing-masing pertanyaan tersebut tampak dari reaksi subjek yang bersifat pribadi sekali atas pertanyaan yang diajukan. Semua jawaban itu tampak jelas sekali sewaktu anda melaksanakan apa yang ditanyakan.

3. Dengarkanlah pertanyaan-pertanyaan yang diajukan dan janganlah terpengaruh oleh perasaan-perasaan yang aneh dan tidak enak, atau perasaan apapun yang dirasakan. Tangkaplah setiap pertanyaan sebagaimana biasanya anda memberikan reaksi atas pertanyaan biasa.

4. Reaksi atas pertanyaan-pertanyaan itu adalah jawaban yang benar-benar untuk diri sendiri.

Di akhir terapi dilakukan evaluasi dan subjek diminta untuk melakukan terapi di rumah secara mandiri. 


\section{Teknik Analisis Data}

Seperti yang diungkapkan di atas bahwa penelitian ini menggunakan desain ABA. Mula-mula target behavior diukur secara kontinyu pada kondisi baseline (A) dengan periode waktu tertentu kemudian diukur lagi pada kondisi intervensi (B) setelah itu baru kemudian dilakukan lagi pengukuran pada kondisi A yang kedua. Adapun metode penilaian dan pengukuran pada penelitian ini adalah dengan menggunakan range tingkat kecemasan SUDS (Martin \& Pear, 2003), self monitoring dan dengan BAl (Beck Anxiety Inventori) yang masing-masing diberikan saat pra intervensi, selama intervensi, dan setelah intervensi. Proses penilaian dan pengukuran tersebut dilakukan untuk mengetahui apakah teknik relaksasi kesadaran indera yang telah diterapkan mampu membantu menurunkan kecemasan pada penderita diabetes melitus.

\section{HASIL PENELITIAN}

\section{Deskripsi Subjek}

Dari penelitian ini didapatkan hasil sebagai berikut:

\section{Tingkat kecemasan yang diperoleh dari BAI}

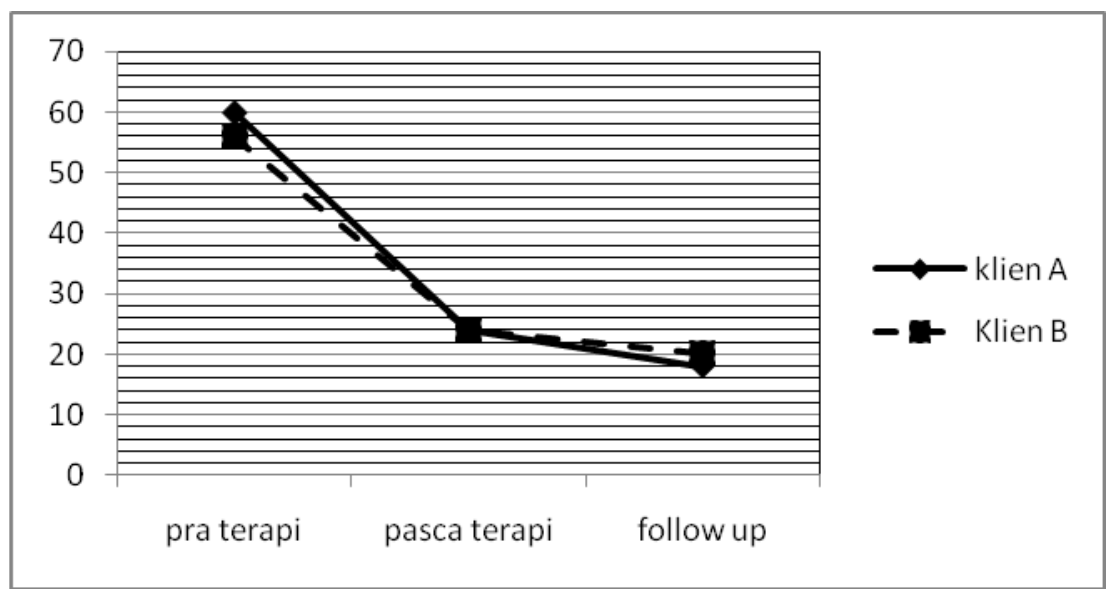

Gambar 1. Gafik penurunan kecemasan berdasarkan hasil BAI 
2. Tingkat kecemasan yang diperoleh dari hasil SUDs

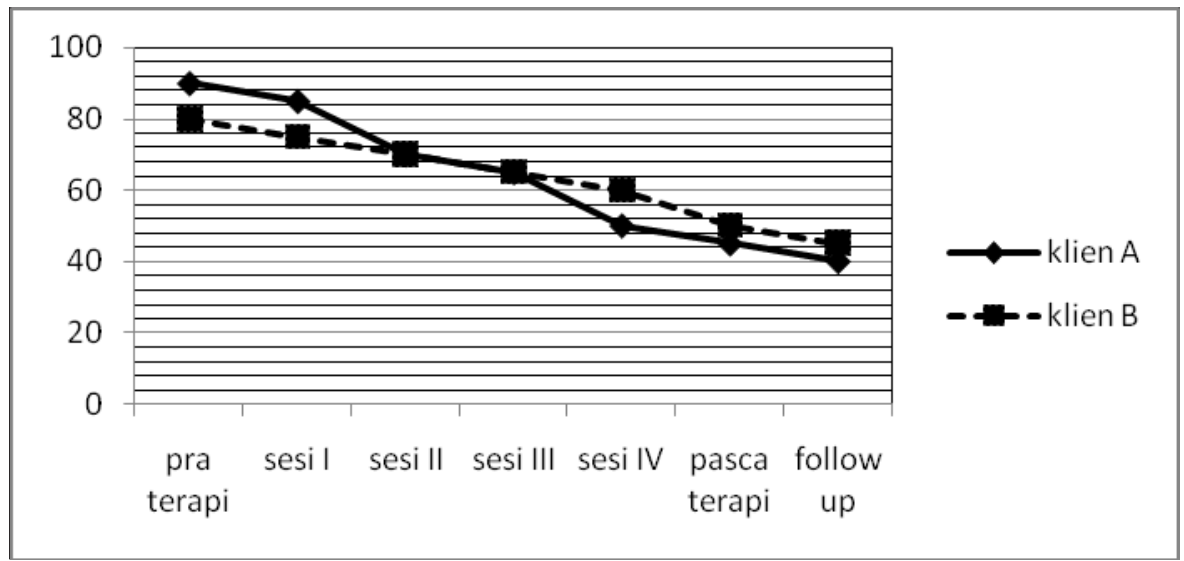

Gambar 2. Grafik penurunan tingkat kecemasan berdasarkan SUDs

Dari gambar di atas tampak jelas terjadi penurunan tingkat kecemasan yang dirasakan klien pada setiap proses terapi mulai dari pasca terapi. Dalam proses ini tidak dilakukan treatment pada klien sehingga tampak tingginya tingkat kecemasan yang terjadi pada diri klien. Namun terjadi penurunan ketika sesi I diberikan dengan melihat hasil dari SUDs klien. Pada sesi I ini terjadi penurunan sekitar sekitar 5 poin pada klien HP maupun klien RA. Sedangkan pada sesi kedua terjadi penurunan yang lumayan besar bagi klien RA, yaitu sekitar 15 poin, sedangkan bagi klien HP penurunan yang terjadi hanya sebesar 5 poin.

Pada sesi III, klien RA mengalami penurunan sekitar 5 poin. Penurunan yang terjadi tampak tidak terlalu besar karena sehari sebelum sesi III dilakukan, klien mengalami situasi yang membuat dirinya menjadi cemas, yaitu melihat ada tetangga mertuanya yag meninggal akibat komplikasi diabetes. Ketika itu klien merasa sangat cemas, namun kemudian klien langsung melakukan relaksasi kesadaran indera ini sendiri dirumah mertuanya. Ketika itu klien merasa simptom kecemasan yang dirasakannya tidak terlalu parah jika dibandingkan sebelum klien mengkuti terapi relaksasi ini. Saat itu klien merasa kecemasannya sekitar 80, namun klien terus melatihkan relaksasi kesadaran indera secara mandiri sehingga kecemasannya mulai berkurang. Sedangkan pada klien HP terjadi penurunan sekitar 5 poin lagi dari sebelumnya.

Pada sesi IV, klien RA mengalami penurunan sekitar 15 poin, sedangkan klen HP sekitar 5 poin. Setelah sesi IV ini kemudian dilakukan sesi pasca terapi 
di mana pada saat itu klien RA merasa kecemasannya turun sekitar 5 poin. Hal ini disebabkan pada saat itu klien mulai sibuk karena ada proyek dari kantor yang harus diselesaikan sehingga klien RA hanya bisa melakukan latihan relaksasi ini sekali sehari. Sedangkan pada klien HP penurunan terjadi 5 poin.

Setelah pasca terapi kemudian proses terapi dihentikan sampai sekitar seminggu baru kemudan dilakukan follow-up karena kedua klien mulai memiliki kesibukan dengan pekerjaannya. Pada saat follow-up klien RA mengalami penurunan 5 poin. Menurut klien RA dirinya merasa lebih baik dan setiap mengalami situasi yang biasanya menimbulkan kecemasan dirinya langsung melakukan relaksasi kesadaran indera ini dan hasilnya, dirinya merasa tenang dan bisa mengontrol perasaannya. Sedangkan pada klien HP terjadi penurunan sekitar 5 poin.

\section{PEMBAHASAN}

Berdasarkan hasil penelitian yang sudah dipaparkan di atas tampak bahwa terapi relaksasi kesadaran indera dapat menurunkan tingkat kecemasan terhadap penyakit kronis yang dialami oleh klien.

Keluhan yang dirasakan oleh klien merupakan dampak dari rasa cemas yang dirasakan klien karena ketakutan akan semakin parahnya penyakit diabetes yang dialaminya. Penderita kecemasan sering mengalami gejala-gejala seperti berkeringat berlebihan walaupun udara tidak panas dan bukan karena berolahraga, jantung berdegup ekstra cepat atau terlalu keras, dingin pada tangan atau kaki, mengalami gangguan pencernaan, merasa mulut kering, merasa tenggorokan kering, tampak pucat, sering buang air kecil melebihi batas kewajaran dan lain-lain. Mereka juga sering mengeluh pada persendian, kaku otot, cepat merasa lelah, tidak mampu rileks, sering terkejut, dan ada kalanya disertai gerakan-gerakan wajah atau anggota tubuh dengan intensitas dan frekuensi berlebihan, misalnya pada saat duduk terus menerus, menggoyang-goyangkan kaki, meregangkan leher, mengernyitkan dahi dan lain-lain (Gunarsa, Setiadarma, \& Soekasah, 1996).

Kecemasan merupakan kebingungan, kekhawatiran pada sesuatu yang akan terjadi dengan penyebab yang tidak jelas dan dihubungkan dengan perasaan tidak menentu dan tidak berdaya dan kecemasan tidak dapat dihindarkan dalam kehidupan sehari-hari. Kecemasan adalah perasaan ketakutan (baik realistis maupun tidak realistis), yang disertai dengan keadaan peningkatan reaksi kejiwaan yang menyatakan kecemasan sebagai emosi yang tidak menyenangkan yang ditandai dengan istilah seperti khawatir, prihatin dan rasa takut yang kadang-kadang dialami dalam tingkat berbeda (Atkinson dkk, 1993). Jadi dapat disimpulkan bahwa kecemasan merupakan keadaan suasana hati yang ditandai oleh efek negatif, di mana 
seseorang mengantisipasi kemungkinan datangnya bahaya atau kemalangan di masa yang akan datang dengan perasaan khawatir atau takut.

Pada umumnya pasien diabetes mencoba untuk mematuhi manajemen diabetes yang ada namun lebih sering kesulitan untuk mematuhinya karena dipengaruhi oleh penerimaan mereka terhadap simptom-simptom dalam diri mereka seperti keengganan atau keadaan emosi mereka (Sarafino, dalam Hasanat, 2008). Reaksi emosi yang muncul dalam diri pasien diabetes tidak hanya memengaruhi kepatuhan pasien dalam diet namun juga memengaruhi kehidupan psikologis dan kualitas hidup pasien tersebut (Miller \& Schnoll, 2000).

Paparan di atas sama dengan yang dialami oleh klien dalam penelitian ini, sehingga diputuskan untuk diberikan terapi relaksasi kesadaran indera dengan tujuan untuk mengurangi kecemasan klien sehingga dapat berakibat baik untuk fisik klien. Pemberian relaksasi ini bertujuan agar klien bisa merasakan tenang dan rileks terutama ketika klien menghadapi situasi-situasi yang dapat menimbulkan kecemasan bagi klien.

Terapi relaksasi kesadaran indera merupakan salah satu teknik terapi yang berupa pemberian instruksi kepada seseorang dalam bentuk pertanyaan yang tersusun secara sistematis. Pertanyaanpertanyaan ini dimaksudkan agar individu yang melakukan relaksasi bisa benar- benar merasakan rileks dan perasaan nyaman. Relaksasi kesadaran indera ini memfokuskan individu untuk bisa merasakan tubuhnya sendiri khususnya panca indera sehingga individu bisa merasakan ketenangan (Gordfried \& Davison, 1976).

Setelah menjalani beberapa sesi dari terapi relaksasi kesadaran indera ini tampak adanya penurunan tingkat kecemasan pada diri klien. Klien yang awalnya memiliki tingkat kecemasan tinggi bisa turun dan berada pada taraf kecemasan sedang. Penurunan kecemasan yang terjadi pada klien karena klien membiarkan dirinya merasa rileks dan tenang sehigga bekerja saraf simpatetis yang akan menimbulkan perasaan tenang tersebut. Dalam proses ini klien juga mengalami proses belajar, bahwa ketika dirinya mengalami ketegangan dan kecemasan maka akan diikuti juga dengan terjadinya keluhan fisik yang bisa memberi andil bagi penyakitnya. Disini klien belajar untuk mengembangkan sebuah perilaku baru yang lebih baik dalam menyikapi kecemasannya yaitu dengan melakukan relaksasi kesadaran indera. Hal ini sesuai dengan teori behavioristik di mana perilaku diarahkan pada tujuan-tujuan memperoleh perilaku baru dan menghapus perilaku lama yang maladaptive serta mempertahankan perilaku perilaku yang diinginkan (Corey, 2007).

Tingkat kecemasan kedua klien mengalami penurunan sampai pada 
tahap sedang yang artinya bahwa kedua klien ini sudah tidak merasakan simptom kecemasan yang berat dan bisa membuat mereka tidak bisa bertahan. Jadi klien merasa symptom kecemasan yang mereka rasakan masih ada namun tidak begitu mengganggu mereka. Hal ini juga sama seperti hasil penelitian yang dilakukan Goldfried dan Trier (Subandi, 2002) menunjukkan efektivitas latihan relaksasi yang disajikan sebagai self control coping skill. Penelitian tersebut menunjukkan bahwa subjek yang diberi latihan relaksasi sebagai self control coping skill secara signifikan menunjukkan pengurangan kecemasan yang lebih besar daripada subjek yang diberi latihan relaksasi yang disajikan sebagai prosedur otomatis untuk mengurangi kecemasan.

Menurut pengalaman klien, mereka bisa merasakan relaksasi yang lebih dalam karena klien bisa merasakan masuk lebih jauh kedalam keadaan yang relaks. Klien A juga mengalami hal ini ketika sholat sehingga klien A mendapatkan kesimpulan bahwa proses relaksasi ini juga dapat dirasakan ketika sedang sholat. Proses inilah yang mirip dengan proses relaksasi kesadaran indera. Relaksasi sebagai jalan menuju alam bawah sadar akan mengendalikan dan menyelaraskan fungsi-fungsi tubuh, seperti memompa darah keseluruh tubuh, mengendalikan pernapasan dan pencernaan.

\section{SIMPULAN}

Berdasarkan hasil penelitian yang telah dilakukan didapatkan hasil bahwa penerapan teknik relaksasi kesadaran indera yang dilakukan secara terus menerus (sehingga menjadi perilaku copying) pada klien yang mengalami kecemasan terhadap penyakit diabetes ternyata dapat mengurangi simptom kecemasan yang dirasakan oleh klien.

Adapun perubahan yang dirasakan klien yakni berkurangnya simptom kecemasan yang dirasakan klien setelah melakukan relaksasi kesadaran indera baik dengan terapis maupun yang dilakukan klien sendiri dirumah. Hal ini ditunjukkan dari hasil SUDs dan BAI yang diberikan kepada klien. Selain berkurangnya simptom kecemasan klien juga merasakan adanya penurunan symptom penyakit diabetes yang dirasakan oleh klien, hal ini ditunjukkan dengan hasil laboratorium klien dan cek tekanan darah yang dilakukan setelah melakukan latihan relaksasi kesadaran indera selama proses terapi berlangsung.

\section{DAFTAR PUSTAKA}

Afiah, N. (2010). Metodelogi Riset Diabetes Mellitus Hubungan Tingkat Kecemasan Dengan Peningkatan Kadar Gua Darah Penderita Diabetes Mellitus Tipe II di RS X. Laporan Penelitian. Fakultas Kesehatan Masyarakat Universitas Hasanuddin Makasar. 
Ambarwati, W. (2008). Hubungan antara persepsi dukungan sosial dengan tingkat kecemasan pada penderita diabetes mellitus. Surabaya. Buletin Penelitian RSU Dr. Soetomo, Volume 10.

Atkinson, R.L. Atkinson, R.C dan Smith, E.E (1993). Pengantar psikologi (jilid 2). Jakarta: Intraksara.

Azwar, S. (1999). Penyusunan skala psikologi. Yogyakarta: Pustaka Pelajar Offset.

Corey, G. (2007). Teori dan praktek konseling dan psikoterapi. Bandung: PT Refika Aditama.

Davis, M., Eshelman, E. R., \& McKay, M. (1995). Panduan relaksasi dan reduksi stres (Terjemahan), Edisi III. Jakarta: Penerbit Buku Kedokteran EGC.

Desminarti, Z. (2003). Efektivitas Latihan Relaksasi Kesadaran Indera dengan Menggunakan Kaset dan Dengan Menggunakan Liflet untuk Menurunkan Kecemasan Penderita Penyakit Kanker Payudara. Tesis (tidak diterbitkan). Yogyakarta: UGM.

Goldfried, M.R. \& Davison, G.C. (1976). Clinical Behavior Therapy. USA: Holt, Rinehart and Winston.

Goleman, D. (1996). Emotional Intelligence. Jakarta: P.T Gramedia Pustaka Utama.
Gunarsa, S.D, Setiadarma, M.P., \& Soekasah, M.H.R. (1996). Psikologi Olahraga: Teori dan praktek. Jakarta : BPK Gunung Mulia.

Hasanat, N.U. (2008). Dinamika Emosi Kepatuhan Diet pada Pasien Diabetes Melitus. Jurnal Penelitian Psikologi, 13(1), 12-20.

Hudak \& Gallo. (1995). Keperawatan Klinis. Jakarta: Buku Kedokteran EGC.

Kaplan \& Sadock. (1997). Sinopsis psikiatri ilmu pengetahuan perilaku psikiatri klinis. Alih Bahasa : Widjaja Kusuma. Jakarta : Binapura Aksara.

Kartika, K.I dan Hasanat N.U. (2008). Dinamika Emosi Kepatuhan Diet pada Pasien Diabetes Melitus. Jurnal Penelitian Psiklogi, 13. Universitas Gadjah Mada.

Kenyon, F. E. (1985). Psikologi Populer: Berpikir Sehat Mengatasi Kekhawatiran. Jakarta: Arcan.

Latipun. (2002). Psikologi eksperimen. Malang: UMM Press.

Martin, G. \& Pear, J. (2003). Behavior Modification. What it is and How to Do it ( $7^{\text {th }} E d$ ). Upper Saddle River, NJ: Prrentice-Hall.

Miller, S.M. \& Schnoll, R. A. (2000). Handbook of Emotions: Second Edition. New York: The Guilford. 
Monte, C. F., \& Sollod, R. N. (2003). Subandi, M.A. (2002). Psikoterapi: Beneath The Mask: An Introduction Pendekatan konvensional dan to Theories of Personality (7th ed). kotemporer. Yogyakarta: Unit Hoboken, NJ: John Wiley \& Son. Fakultas Psikologi UGM .

Pratiwi. R. (2010). Pengertian Kecema- Sugiyono. (2010). Memahami penelitian san. www.psikologi.co.id. kualitatif. Bandung: Alfabeta.

Purwanto, S. (2006). Relaksasi Dzikir. Susanti, R. (2009). Teknik relaksasi. Surakarta: Fakultas Psikologi Univer- Makalah, Universitas Negeri sitas Muhammadiyah Surakarta.

Ramdhani, N \& Putra, A.A. Pengembangan multimedia relaksasi. Laporan Penelitian. Yogyakarta. Fakultas Psikologi Universitas Gadjah Mada.

Semium, Y. (2006). Teori Kepribadian \& Terapi Psikoanalitik Freud. Cetakan 1. Yogyakarta: Penerbit Kanisius. Malang, Retrieved from http://lutfifauzan.wordpress.com/2009/12/29/ teknik-konseling-individu-relaksasi/

Taylor, D. N. (1995). Effects of a behavioral stress-management program on anxiety, mood, self-esteem, and T-cell count in HIV-positive men. Psychological Reports, 76(2), 451-457. 